\title{
International demands for austerity: Examining the impact of the IMF on the public sector
}

\author{
Stephanie J. Rickard ${ }^{1}$ (D) Teri L. Caraway $^{2}$
}

Published online: 25 January 2018

(C) The Author(s) 2018. This article is an open access publication

\begin{abstract}
What effects do International Monetary Fund (IMF) loans have on borrowing countries? Even after decades of research, no consensus exists. We offer a straightforward explanation for the seemingly mixed effects of IMF loans. We argue that different loans have different effects because of the varied conditions attached to IMF financing. To demonstrate this point, we investigate IMF loans with and without conditions that require public sector reforms in exchange for financing. We find that the addition of a public sector reform condition to a country's IMF program significantly reduces government spending on the public sector wage bill. This evidence suggest that conditions are a key mechanism linking IMF lending to policy outcomes. Although IMF loans with public sector conditions prompt cuts to the wage bill in the short-term, these cuts do not persist in the longer-term. Borrowers backslide on internationally mandated spending cuts in response to domestic political pressures.
\end{abstract}

Keywords IMF· Public sector · Conditionality · Government spending · Reform • Austerity $\cdot$ Wage bill $\cdot$ Loan conditions $\cdot$ Public sector employment · Backsliding

What effects do International Monetary Fund (IMF) loans have on borrowing countries? Even after decades of research, no consensus exists on this topic. Scholars

Electronic supplementary material The online version of this article (https://oi.org/10.1007/s11558-0179295-y) contains supplementary material, which is available to authorized users.

Stephanie J. Rickard

S.Rickard@1se.ac.uk

Teri L. Caraway

caraway@umn.edu

1 London School of Economics, London, UK

2 University of Minnesota, Minneapolis, USA 
disagree about how IMF loans affect countries' economic growth, public expenditures, poverty, and income distributions (Oberdabernig 2013; Nooruddin and Vreeland 2010; Nooruddin and Simmons 2006; Nsouli et al. 2004; Dreher 2006; Bulír and Moon 2004; Clements et al. 2013; Garuda 2000; Hajro and Joyce 2009; Kentikelenis et al. 2015; Vreeland 2002; Bas and Stone 2014). Scholars also disagree about the mechanisms through which IMF loans work (Dreher 2009; Vreeland 2006). Do IMF loans exert their influence indirectly through signaling to market actors, for example, or directly via the conditions attached to countries' loan programs?

Conditions are one of the most contentious features of IMF lending. The "conditions" attached to countries' loan programs stipulate policy reforms required in exchange for IMF financing. Since the 1970s, the IMF has provided countries with financial assistance contingent on the implementation of specific policies (Dreher 2009, 233). The policy reforms required in exchange for IMF financing are stipulated in the loan's conditions, which often require changes with major distributive consequences. Because the reforms often entail substantial political costs, borrowers sometimes fail to comply with their loan conditions (Easterly 2001; Bird and Willett 2004; Ivanova et al. 2003; Dreher 2003; Steinwand and Stone 2008; Vreeland 2006; Joyce 2004). If countries do not comply with their loan conditions, then the observed effects of IMF lending must occur through other mechanisms.

Questions about whether IMF loan conditions "matter" are therefore deeply connected to compliance (Vreeland 2006). But grappling with the conditionalitycompliance link is complicated because IMF loans often contain many different conditions, and these conditions vary between programs (Gould 2006; Stone 2008; Caraway et al. 2012; Copelovitch 2010; Vreeland 2006). If conditions differ between loans, and conditionality is a key mechanism through which IMF lending works, then IMF programs should have varying effects. Yet most investigations of IMF lending fail to account for the variation in loan conditions. Instead, they treat all IMF programs as being identical and expect them to have a single, invariant effect on borrowers. ${ }^{1}$ Similarly, scholars typically assess compliance through measures that pertain to whole IMF programs (e.g., program suspension) (Steinwand and Stone 2008). But most countries' loan programs include multiple conditions, and if some conditions are more difficult to implement than others, borrowers may comply with only a fraction of their total conditions. Compliance, in other words, is not an all or nothing proposition.

Large- $\mathrm{N}$ quantitative studies have yet to provide a convincing test of whether loan conditions are a central mechanism through which IMF lending impacts borrowing countries. We aim to provide such a test. We argue that IMF loans with different conditions should have different effects if conditionality is one of the mechanisms linking IMF loans to policy outcomes. To this end, we take up Vreeland's (2006) proposal that scholars adopt a disaggregated approach to studying the effects of IMF lending by connecting specific conditions to specific outcomes. We examine whether specific loan conditions have measurable effects on borrowing countries' spending decisions. We do so through an analysis of a substantively important and politically sensitive topic: loan conditions that require cuts to the public sector wage bill.

\footnotetext{
${ }^{1}$ Scholars often use a simple dichotomous variable to indicate whether a country is participating in an IMF program or not.
} 
The public sector wage bill is often the single largest expenditure in governments' budgets. It comprises almost $30 \%$ of total government expenditure in lower income countries on average (Das 1998, 16; Forni and Novta 2014, 5). Given this, the public sector wage bill presents an inviting target for cuts. But slashing the wage bill risks compromising essential functions and can provoke protests from powerful constituencies. Governments therefore tend to be averse to cutting the public sector wage bill (Bienen and Gersovitz 1985; Shepherd 2003; Nooruddin and Vreeland 2010).

While virtually all IMF loans contain general fiscal conditions that require governments meet an aggregate spending limit, most loans do not specify cuts to the public sector wage bill. In fact, only $25 \%$ of IMF programs include conditions that explicitly require cuts to the public sector. If conditionality is one of the mechanisms through which IMF lending affects outcomes, then countries that receive public sector conditions should respond differently than countries that do not. We hypothesize that borrowers who receive a condition that targets the public sector will make deeper cuts to the public sector wage bill than those who do not. Borrowers who receive targeted public sector conditions must cut the wage bill or risk losing access to IMF funding. In contrast, governments facing only general fiscal targets will make cuts to less politically sensitive budget items.

Using novel data on IMF loan conditions, we find that seemingly small differences in the content of conditions has measureable effects on borrowers' behavior. Countries that receive conditions specifically targeting the public sector make deeper cuts to the public sector wage bill than countries that do not receive such conditions in their IMF program. This finding demonstrates both the utility and importance of disaggregating IMF loan conditions. Because most IMF loans do not mandate cuts to the public sector, any study that did not account for this fact would likely reach erroneous conclusions about the effects of IMF lending on public sector reform. As we show, IMF loans with public sector conditions reduce government spending on the public sector wage bill by more than IMF loans without public sector conditions. ${ }^{2}$

Although IMF loans with public sector conditions prompt cuts to the wage bill in the short-term, our results suggest that such cuts may be temporary. Using an error correction model, we estimate the short- and long-term effects of adding a public sector condition to a country's IMF program. While public sector conditions engender significant short-term cuts to the wage bill, these cuts do not persist in the longer-term.

The selection of a politically sensitive and contentious issue, public sector reform, sets up a hard test for assessing whether IMF conditions matter. If conditionality can exert an effect on the public sector, then IMF loan conditions should also be able to affect other less politically volatile policy areas. We speculate about, but leave for future research, the possibility that IMF conditions in other areas may be more successful in stimulating long-term change.

The rest of our paper develops as follows. First, we discuss the emergence of the size of the public sector as a policy problem and describe the prevalence of targeted loan conditions. We then present our theoretical argument and conduct several empirical tests that assess whether borrowing countries that receive targeted conditions prune

\footnotetext{
${ }^{2}$ It is important to note that our results pertain only to the subset of countries that borrow from the IMF because we examine only countries with IMF programs. However, governments may cut the public sector in the absence of an IMF program.
} 
spending on public sector wages more deeply than those that do not receive these conditions. We conclude with a discussion of the broader implications of our findings.

\section{The size of the public sector as a policy problem}

The size of the public sector became a focus of international attention in the 1980s as ideas about the reduced role of the state in the economy gained traction (Rapley 2002). The election of Ronald Reagan in the United States and Margaret Thatcher in the United Kingdom, and the emergence of the "Washington Consensus" in international financial institutions, provided the political and institutional muscle for ideas about the optimal size of the public sector to influence policy design. Policymakers soon began to identify the size of the public sector as a problem that needed to be addressed (Biersteker 1990; Nunberg and Nellis 1992; Stevenson 1992; Goldsmith 1999; Lee and Strang 2006). ${ }^{3}$ The fiscal crises that beset many developing countries in the 1980s gave advocates of public sector downsizing increased leverage to advocate for these changes (Biersteker 1990). Shrinking "bloated bureaucracies" and pruning spending on public sector compensation became the means through which countries would put their fiscal houses in order and their economies on the right path (Nunberg and Nellis 1992; Rama 1999; Rodrik 2000).

These ideas about the public sector as a problem in need of a solution affected policy prescriptions in developing countries in part because the size of the civil service increased rapidly in most developing countries in the 1960s and 1970s (Das 1998; Goldsmith 1999; Rodrik 2000). Several factors drove these increases. First, civil services were usually small at independence and needed to be larger to perform important state functions (Goldsmith 1999). Second, state-led development increased public sector employment in the civil service and state-owned enterprises (Rama 1999; Rodrik 2000). Third, expanding public sector employment served important political functions by employing educated people in urban areas and serving as a valuable source of patronage (Gelb et al. 1991; Lindauer 1994; Das 1998; Goldsmith 1999; van de Walle 2001; Shepherd 2003). Lastly, government employment is a social insurance mechanism in small open economies vulnerable to shocks (Rodrik 2000) and a means to compensate important constituencies negatively affected by globalization (Nooruddin and Rudra 2009). Despite these pressures to expand public employment, the size of the public sector in developing countries is relatively small in comparison to OECD countries (Schiavo-Campo et al. 1997). ${ }^{4}$ But the perception of bloated bureaucracies and excessive spending on compensation had powerful ideological and institutional support, and policy prescriptions increasingly called for reform.

Setting aside debates about the "right" size of the public sector, the fiscal crisis in developing countries put tremendous pressure on government budgets (Lindauer 1994; Goldsmith 1999). The fiscal burden of public sector wage bills caused particular concern (Nunberg and Nellis 1992; Stevenson 1992). The wage bill is usually the

\footnotetext{
${ }^{3}$ As Lee and Strang (2006) note, the perceived problem of oversized bureaucracies resulted in privatization and retrenchments in OECD countries.

${ }^{4}$ Public sector employment, however, constitutes a larger share of the non-agricultural workforce in developing countries and is also a large share of formal sector employment (Nunberg and Nellis 1992).
} 
single largest item of government expenditure and comprises almost $30 \%$ of government budgets in lower income countries (Das 1998, 16; Forni and Novta 2014). If governments had access to additional revenue, they might sustain spending on public sector compensation. However, raising revenues is challenging for governments in developing countries, so they typically have to cut expenditures to correct fiscal imbalances (Independent Evaluation Office 2003; Bulír and Moon 2006; Nooruddin and Simmons 2006). Despite the importance of the public sector wage bill in government budgets, however, the IMF does not always require cuts to this budget area; this variation in IMF loan conditions has important consequences for government spending.

\section{Why variation in IMF loan conditions matters}

Governments in economic crisis have compelling reasons to cut expenditures. What budget items do they cut and why? We argue that governments try to avoid cutting the public sector because doing so is politically costly. Governments who borrow from the IMF will only make significant cuts to the public sector if required to do so as an explicit condition of their loan. Governments want to protect the public sector wage bill for two reasons. First, public sector employment helps assure political stability by providing work to educated people in urban areas (Gelb et al. 1991; Lindauer 1994; Das 1998; Goldsmith 1999; van de Walle 2001; Shepherd 2003). A large share of nonagricultural employees in most developing countries work in the public sector, and these jobs are an important social insurance mechanism, particularly in small open economies vulnerable to shocks (Rodrik 2000). The geographic concentration of public sector employees in urban areas and the greater likelihood that these citizens belong to organizations that facilitate mobilization increases the potential for disruptive protests, especially when few other attractive job opportunities exist in the formal sector.

Second, public sector jobs serve as a valuable source of patronage for key constituencies and regime supporters (Shepherd 2003; Chandra 2007; Petersson 1993; Khabele 1990). Politicians can use the allocation of public sector jobs to build their power bases, reward supporters, and co-opt other groups (Chandra, 2004; Nooruddin and Rudra, 2014; Calvo and Murillo, 2004; Keefer, 2007; Remmer, 2007). Even autocracies will be averse to cutting the public sector, since ruling regimes typically rely on a small coalition of loyal supporters - not a plurality of voters - for political survival (Bueno de Mesquita et al. 2003), and public sector jobs are a particularly effective means to such purchase support (Lust-Okar 2006; Greene 2007; Magaloni 2008; Aidi 2009; Gandhi 2010; Blaydes 2011). The distribution of public sector jobs is credible, targeted, and reversible, making it an ideal way for leaders to reward key supporters (Robinson and Verdier 2013).

Since reductions to the public sector wage bill may undercut leaders' support and threaten their political survival, governments try to protect spending on public sector wages and salaries, even when they face heavy debt burdens (Mahdavi 2004). However, if economic circumstances compel them to borrow from the IMF, governments may be required to prune spending. Reducing the budget deficit is a central component of most IMF programs, so fiscal conditions of one sort or another are omnipresent in IMF loans (Bulír and Moon 2006). However, fiscal conditions take varied forms, and their variations have important consequences for a government's ability to protect 
the public sector wage bill. The relevant distinction for the wage bill is between general and targeted fiscal conditions.

General fiscal conditions require governments to spend less than a specified aggregate spending limit. General conditions are by far the most common type of fiscal condition attached to loans. Between 1983 and 1990, 91\% of IMF loans included general fiscal conditions and from the early 1990s, $100 \%$ of IMF loans included them (Gould 2006, 90). Governments that receive general fiscal conditions must meet the specified spending limit but have flexibility as to which items they must cut in order to meet the aggregate target. Governments with such autonomy will focus on easy targets - cutting spending on programs associated with the least organized and least politically influential interests (Nooruddin and Simmons 2006). Governments will protect programs that affect well-organized, politically powerful groups, such as public sector workers.

Targeted fiscal conditions, in contrast, require cuts to specific budget items, such as the public sector wage bill. Benin's 2001 IMF program, for example, included a targeted condition that required the public sector wage bill be reduced to less than $4.6 \%$ of GDP. ${ }^{5}$ Such targeted public sector conditions are relatively infrequent. Only $25 \%$ of IMF loans made during the period from 1980 to 2014 specify limits on or cuts to public sector employment or wages as a condition of the loan. ${ }^{6}$ Governments that receive conditions targeting the public sector wage bill cannot shift cuts to other budget items without risking delays or suspensions of subsequent disbursements of funds. Although the IMF sometimes waives conditions and continues disbursements despite noncompliance, the Fund at times exercises its power to suspend loans when countries fail to comply with their loan conditions (Ivanova et al. 2003). Consequently, noncompliance entails some risk. Even if the loan is not suspended, governments may fear the reputation costs of non-compliance with IMF conditions. Foreign investors may view negatively a governments' unwillingness to reform. In order to minimize the reputation costs of non-compliance and the risk of loan suspension, we anticipate that borrowers who receive targeted conditions will attempt to make some progress on them even if they do not completely meet the target. By making headway, the government shows good faith, which reduces the chances of loan suspension. We therefore hypothesize that targeted public sector conditions will engender deeper cuts to the wage bill than general fiscal conditions, all else equal.

Egypt and Tanzania provide good illustrations of the logic of our argument. In Tanzania, the IMF program stipulated targeted public sector conditions. Every year of Tanzania's 3-year ESAF arrangement (1996-99) included conditions that required the government to reduce the number of public sector employees and/or set limits on budget expenditures on public sector wages and salaries. Given the targeted nature of these conditions, the government could not avoid making cuts to the public sector without jeopardizing their IMF program. The government met all of the public sector conditions, albeit in one case tardily, and by the end of the program, civil service employment had fallen by $8 \%$ (Independent Evaluation Office 2003). In contrast, Egypt received no targeted public sector conditions in their 1991 loan. Instead, the IMF required the Egyptian government to meet an aggregate fiscal deficit

\footnotetext{
5 http://www.imf.org/external/np/loi/2001/ben/01/index.htm

${ }^{6}$ More precisely, $25 \%$ of loan-country-years.
} 
target. ${ }^{7}$ The government met its deficit target even though it increased spending on the public sector wage bill by $12 \%$. They achieved this outcome by increasing domestic energy prices and fees, raising customs duties, and terminating some tax holidays. ${ }^{8}$

IMF loans engender varied responses by borrowing governments, as these two cases illustrate. Following the receipt of an IMF loan, the Tanzanian government cut the wage bill while the Egyptian government increased spending on the wage bill. The varied governmental responses stem from the conditions attached to each country's IMF loan. Consistent with our argument, the government that received targeted public sector loan conditions (Tanzania) cut the wage bill while the government with general fiscal conditions (Egypt) did not. As these examples show, identifying the precise conditions included in countries' loan programs can improve understanding of the impact of IMF loans on borrowing countries.

\section{Public sector conditions dataset}

To identify the conditions attached to countries' IMF loans, we scrutinize the Letters of Intent (LOI), which are normally drafted by IMF staff after negotiating with borrowing governments. The Letters of Intent, and the frequently attached Memorandum of Economic and Financial Policies (MEFP), stipulate the loan's conditions. Upon agreement of the conditions, national executives, typically the Minister for Finance and/or the Governor of the Central Bank, sign the LOI/MEFP.

We examine the LOI/MEFP for all IMF loans made during the period from 1980 to 2014. We identify and code conditions that stipulate limits on or cuts to public sector wages and/or employment. We refer to these conditions as "public sector conditions." Public sector conditions include ceilings on the amount of money spent on the compensation of public sector employees (Clements et al. 2010, 6). For example, Burkina Faso's 2005 loan stipulated that the wage bill must not exceed 69.7 billion West African CFA francs. ${ }^{9}$ To meet a ceiling on wage bill spending, governments may cut or temporarily freeze public sector wages (Clements et al. 2010, 6). The Irish government, for example, cut public sector wages by 5 to $8 \%$ to fulfill the terms of their 2010 loan program. ${ }^{10}$ Public sector conditions also include mandatory hiring freezes, which when combined with natural attrition, can reduce the wage bill (Clements et al. 2010, 7). Public sector conditions may also require mandatory lay-offs. Uganda's 1993 loan, for example, required that 65,000 employees be removed from the civil service. A condition of Bulgaria's 2006 loan was, "an employment cut of at least 5,500 positions in the education sector." 11 Dismissals and hiring freezes reduce the number of people employed in the public sector and consequently help to shrink the wage bill.

Our original data differ from existing data on IMF conditionality in several ways, as illustrated by Table 1. First, our dataset identifies conditions that require limits on or

\footnotetext{
${ }^{7}$ The IMF did not include targeted conditions despite its view that Egypt needed public sector reform. The IMF asked, but did not require, the government to reduce the real wage bill by $15 \%$ in 1992/93.

${ }^{8}$ See IMF documents EBS/93/7/S1 and EBS/93/7.

9 http://www.imf.org/external/np/loi/2005/bfa/081605.pdf

${ }^{10} \mathrm{http} / / /$ www.eurofound.europa.eu/eiro/2009/12/articles/IE0912029I.htm

${ }^{11} \mathrm{http}: / / w w w . i m f . o r g /$ external/np/loi/2006/bgr/071706.pdf
} 


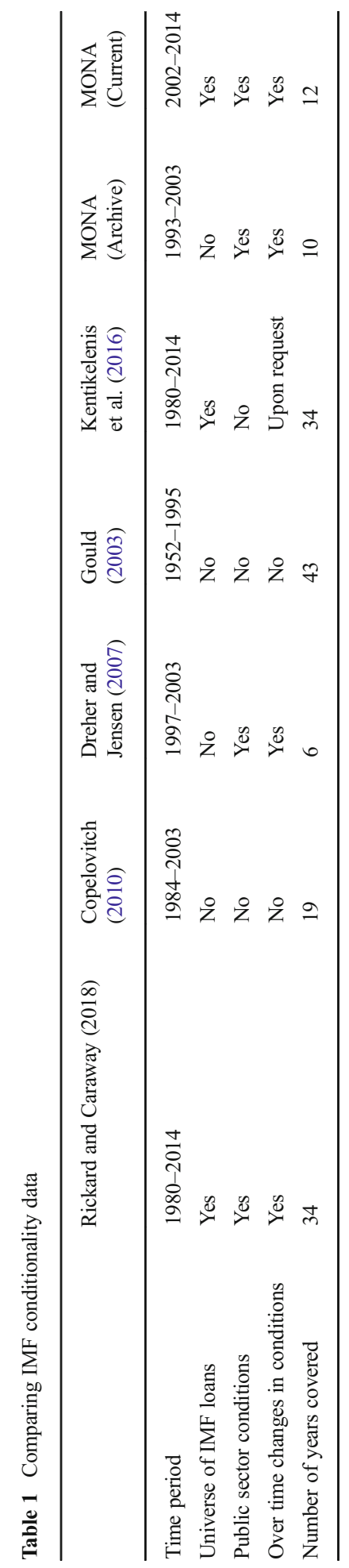


cuts to public sector wages and/or employment. Some datasets do not disaggregate conditions - that is, they focus on the total number of conditions included in a country's loan program (e.g. Copelovitch 2010). Among those that do disaggregate conditions, most do not identify public sector conditions. Gould (2003), for example, examines "bank-friendly" conditions. Caraway et al. (2012), Rickard and Caraway (2014) and Kentikelenis et al. (2016) report data on "labor market" conditions but this category pools together both public and private sector labor market reform conditions. Dreher and Jensen (2007) have a category labelled "public sector" conditions. However, this category may include public sector conditions that are not intended to affect the wage bill, such as those requiring the drafting of civil service reform legislation. The IMF's Monitoring of Fund Arrangements (MONA) dataset lists loan conditions but it is difficult to determine which ones target public sector wages or employment using MONA's categories. ${ }^{12}$ Additionally, "information in the MONA database...may be incomplete or ambiguous in certain instances. Not all structural benchmarks are well recorded" (Mercer-Blackman and Unigovskaya 2004, 81).

Second, our dataset includes all loan programs. Every IMF program agreed during the period from 1980 to 2014 for which loan documents are available is included in our sample. ${ }^{13}$ In contrast, other datasets examine only a subset of loans. Gould (2003) investigates just 20 countries' loans. More ambitiously, Dreher and Jensen (2007) examine 38 countries.

Third, our data cover a substantial number of years (34) and include the most recent decade. Although Gould (2003) examines a longer period (43 years), her sample ends in 1995. Copelovitch (2010) covers 19 years ending in 2003. Dreher and Jensen's (2007) data cover 6 years ending in 2003. MONA covers the period from 1993 to 2014. However, the archived data (1993-2002) are formatted differently than the current data (2002-2014) and coverage for 1993-2002 period is less comprehensive than ours because many loans are not included in their archived data for unknown reasons. Only Kentikelenis et al. (2016) have the same scope as our data in terms of years and countries, but they do not code public sector conditions.

\footnotetext{
${ }^{12}$ MONA is not an off-the-shelf data set that can be easily utilized for data analysis. The archived data (19932002) are formatted differently than the current data (2002-2014). The current MONA data are more comprehensive, and each entry in the data set is a unique condition-economic category pair for each phase of the loan. Given this structure, further manipulation is required in order to ascertain the total conditionality in a given year for a given type of condition. The same condition often appears under multiple economic categories and conditions continue to be listed in the coding for review documents even after the conditions have been met. Care must be taken not to count each entry as a new or continuing condition. The data set is essentially a summary of conditions attached to the initial loan and to subsequent reviews, and the status of each condition (e.g., met, delayed) at the time of each review.

${ }^{13}$ For the period 1980-2000, we directly coded conditions from loan documents obtained in the IMF archive. For 2001-2014, we relied on several publicly available online sources to determine whether loans contained the relevant public sector conditions. We first inventoried all loans, including their beginning and end dates, by compiling a list of arrangements from each country's "Financial Position in the Fund" page on the IMF website. We then scrutinized MONA for the conditions listed under the relevant list of "Economic Descriptors" (e.g., Civil Service and Public Employment, Wages, Expenditures) for conditions that met our coding criteria. We then reviewed the relevant loan documents on the IMF's website in order to review them more carefully and to ascertain the date of the review. Finally, we also sampled at least one set of documents from each loan to ascertain whether indicative targets for public sector wages, which are not coded in MONA, were in place during the loan period.
} 
Finally, and perhaps most importantly, our dataset includes changes in loan conditions over time. Many IMF loans span multiple years and the conditions often change over the life of a loan. The Fund typically updates conditions when it reviews a country's performance and when it issues new arrangement letters. For example, benchmarks are often "upgraded" to performance criteria in subsequent years when a government fails to make significant progress on a reform. Our dataset captures this evolution by coding the conditions in each year of a country's loan program. ${ }^{14}$ As a result, we can identify the precise years in which public sector conditions are added to countries' loan programs.

We code 207 instances of within-country, over-time change in public sector loan conditions. ${ }^{15}$ Honduras, for example, borrowed continuously from 1990 to 1997 . For the first four years, the IMF did not require any public sector reforms in exchange for financing. But in 1995 a public sector condition was added to Honduras' loan program and the government was subsequently obliged to reduce expenditures on public sector employment. Similarly, Bulgaria borrowed from the IMF for eight years without any public sector conditions, but in 1999 the IMF added a public sector condition to Bulgaria's program.

Many previous studies miss these changes in conditionality because they only code the conditions included in the initial loan documents - even for loans that persist over multiple years (e.g., Gould 2003 and Copelovitch 2010). ${ }^{16}$ In contrast, we code the changes in conditions over the duration of a loan program. These data allow us to investigate what happens when a public sector condition is added to a borrower's loan program. In this way, our control group or counterfactual for each country is the country itself under a different treatment status (e.g., under an IMF program without a public sector condition). Many confounding variables are consequently excluded as potential alternative explanations. This empirical strategy is possible because of our novel data on changes in IMF loan conditions over time.

\section{Concerns about endogeneity}

In order to assess the extent to which IMF loan conditions matter, we investigate whether loans that require cuts to the public sector engender deeper cuts to the wage bill than loans without such requirements. Note that we only compare borrowing countries to other borrowing countries - that is, our sample includes only countries with IMF loans. We exploit the variation in borrowers' loan conditions. However, to convincingly draw conclusions about the effects of loan conditions, we must consider the possibility that governments who receive targeted conditions are systematically different from

\footnotetext{
${ }^{14}$ In cases where a country is still in a loan program but during which there is not a review or a new arrangement, we carry forward the conditions from the previous year.

${ }^{15}$ Performance criteria, benchmarks and indicative targets are all included in our "public sector condition" variable. This coding criterion is identical to that employed by the IMF's Independent Evaluation Office (2003). Arguably, this coding strategy biases against finding evidence in support of our hypothesis because it includes "soft conditions" - i.e., benchmarks and indicative targets—which countries can ignore without their loan being automatically suspended.

${ }^{16}$ Although MONA contains the data needed to track changes in conditions over time, the current MONA data do not include the dates of reviews, so one must consult the review documents to find this information.
} 
those who do not. ${ }^{17}$ Governments may, for example, ask for targeted loan conditions in order to make their desired reforms more politically feasible (Remmer 1986, Vreeland 2003). If reform-minded governments ask for targeted conditions in order to "scapegoat" the IMF, any subsequent spending cuts cannot be credited to conditionality alone.

Because we are interested in the extent to which IMF conditions engender domestic reform, we must wrestle with the difficult question of whether governments cut the public sector because they receive targeted conditions, or whether they received targeted conditions because they want to cut the public sector. In other words, we need to assess a government's "political will" for reform (Bird 1996; Vreeland 2003). However, governments' willingness to reform is not directly observable (Wei and Zhang 2010, 77). We therefore build on existing research to identify which governments are most likely to support cuts to the public sector.

Governments from the right of the ideological spectrum tend to be more willing to cut the public sector than left-leaning governments (Garrett and Lange 1991; PopEleches 2009). According to the scapegoating logic, right-governments will therefore be more likely to seek public sector conditions from the IMF because such conditions would provide them with the "political cover" needed to make the desired cuts. If the scapegoating logic is at work, right-governments should receive more public sector conditions than left governments, all else equal. However, we find no evidence of this pattern in our data. In fact, left-governments receive most of the loans with public sector conditions (56\%). This pattern is precisely the opposite of what the scapegoating argument would suggest.

Furthermore, government ideology is not a robust predictor of public sector loan conditions. We estimate a probit model where the dependent variable equals 1 for IMF loans with at least one public sector condition and 0 for loans without any public sector conditions. ${ }^{18}$ Government ideology is not statistically significant in any specification of the model. Right governments are no more likely to receive a public sector condition than left governments, all else equal. In short, governments" "willingness to reform"as estimated by ideology — is not correlated with the receipt of public sector conditions.

Opposition to public sector cuts may be fiercest in countries with larger public sectors. In such cases, reform-minded governments may be especially eager to take

\footnotetext{
${ }^{17}$ In other words, our focus is on the second stage of a two-stage process where the first stage determines the loan conditions and the second stage estimates the effect of these conditions. Ideally, we would estimate a twostage model. However, despite our best efforts, we could not find a suitable instrument for public sector conditions that met the necessary exclusion restrictions. Therefore, following previous studies (Wei and Zhang 2010; Clements et al. 2013; Kentikelenis et al. 2015; Independent Evaluation Office 2003), we control for potential bias due to non-random country selection into loans with public sector conditions by including the inverse-Mills ratio (IMR) in our model (Heckman 1979). These models are reported in the Appendix. The IMR values are generated using a probit model of public sector conditions, which is also reported in the Appendix. A significant negative coefficient on the inverse-Mills ratio would indicate unobserved variables that make a public sector condition more likely are associated with lower spending on the wage bill. However, the IMR is never statistically significant in any of the estimated models. The null results suggest that any unobserved variables that make a public sector condition more likely do not significantly affect government spending on the wage bill. As a further robustness check, we apply the method proposed by Altonji et al. (2005) and Chaudoin et al. (2016) to test how strong selection on unobservables would have to be in order to explain away our results. We find that selection on unobservables would have to be two to three times as strong as selection on observables to account for the entire estimated effect of public sector conditions on the wage bill.

18 These results are reported in the Appendix.
} 
advantage of the "political cover" provided by the IMF. However, the size of a country's wage bill is not a robust predictor of public sector loan conditions. ${ }^{19}$ Countries with larger wage bills are no more likely to receive a targeted condition than countries with smaller wage bills. ${ }^{20}$ In other words, governments facing large public sectors are no more likely to receive a public sector loan condition than governments facing smaller public sectors.

Taken together, this evidence suggests that any selection bias in the allocation of public sector conditions is not working in the way one might suspect. Governments ideologically predisposed to cutting the public sector are no more likely to receive public sector conditions than governments opposed to public sector cuts. In fact, leftleaning governments face relatively more public sector conditions than right-leaning governments. Similarly, governments facing larger public sectors are no more (or less) likely to receive public sector conditions than governments facing smaller public sectors. Any cuts made subsequent to the receipt of a public sector loan condition can therefore be credited, at least in part, to the condition itself.

\section{Government spending on the public sector}

We measure the amount of government spending on the public sector wage bill using data from the World Bank's World Development Indicators (WDI). The WDI data come primarily from the International Monetary Fund's Government Finance Statistics. These data permit comparisons across countries and over time (International Monetary Fund 2014). Governments' conventional accounts are generally not suitable for these purposes because they reflect the organizational structures of government. Organizational changes may consequently distort time-series analyses (International Monetary Fund 2001). However, the IMF's Government Financial Statistics (International Monetary Fund 2014) avoid the problems of organizational differences between countries and allow for meaningful comparisons over time and between countries.

Using these cross-nationally comparable data, we construct a variable, Compensation, which equals the total amount of central government spending on employee compensation as a percentage of GDP. ${ }^{21}$ Spending on employee compensation includes all payments in cash, as well as in kind (such as food and housing), to employees in return for services rendered, and government contributions to social

\footnotetext{
${ }^{19}$ These results are reported in the Appendix.

${ }^{20}$ This finding suggests that IMF loan conditions do not necessarily reflect underlying economic fundamentals. This observation is consistent with others studies that suggest politics - rather than economics aloneshape IMF loan conditions (Caraway et al. 2012; Chapman et al. 2015; Dreher et al. 2015; Nelson 2014; Rickard and Caraway 2014). However, we found no robust political variables in our probit models of public sector conditions. These results raise questions about the universality of scapegoating. Others have raised similar doubts. Nelson (2014), for example, finds that fewer conditions are included in countries' loan programs as the proportion of "neoliberal" leaders in a borrowing government increases. In a similar vein, Caraway et al. (2012) find little evidence that right governments receive tougher labor market reform conditions - of which public sector conditions are a subset.

${ }^{21}$ The central government consists of the institutional units of the central government. The political authority of the central government extends over the entire territory of the country.
} 
insurance schemes such as social security and pensions that provide benefits to employees. $^{22}$ The median sample value of Compensation equals $6 \%{ }^{23}$

\section{Sample and empirical strategy}

Our sample includes only countries under an IMF program. By examining only countries borrowing from the IMF, we sidestep the myriad difficulties that arise when comparing borrowers to non-borrowers (Bulír and Moon 2006; Dreher and Jensen 2007). Countries that borrow from the IMF differ systematically from non-borrowers and comparing the two groups can lead to incorrect inferences. We avoid this pitfall by restricting our sample to only those country-years with an IMF loan program.

Ultimately, we want to know the total impact of public sector conditions on the wage bill. The total impact may include both immediate changes and longer-term effects. More precisely, there are three distinct possibilities: 1) the addition of a public sector condition to a country's loan program may have only contemporaneous effects, where the condition affects Compensation in the short-term, but the effect does not persist into the future; 2) a public sector condition may have a contemporaneous effect as well as a long-run effect that persists across future time periods and decays at some rate; or 3) a public sector condition may have no contemporaneous effect, but instead has a long-run effect, where the effect of a public sector condition on Compensation occurs only across future time periods.

An error correction models (ECM) allows us to estimate and test for all three of these possibilities. ${ }^{24}$ Using an ECM, we can model both long- and short-term forces simultaneously in a single statistical model. This makes it possible to examine directly the longitudinal question of whether changes in IMF loan conditions inspire changes in government spending. To date, this question has been largely neglected because of the lack of data on changes in loan conditions over time. ${ }^{25}$

The error correction model takes the following form:

$\Delta$ (compensation $\left._{\text {it }}\right)=\beta_{0}+\beta_{1} \cdot\left(\right.$ compensation $\left._{i t-1}\right)+\gamma \Delta X_{i t}+\lambda X_{i t-1}+\mu_{i}+\lambda_{t}+\varepsilon_{i t}$,

where $\mathrm{X}$ equals Public Sector Condition, which is coded 1 for loan-years that include a public sector condition and 0 otherwise. $\Delta X_{i t}$ is restricted to non-negative values to designate the addition of a public sector condition to a country's loan program. $^{26}$ The dependent variable is the annual change in Compensation in country, $i$, for year, $t$. Calculating the year-to-year difference in Compensation eliminates concerns about the distribution of the level variable because the differenced variable

\footnotetext{
${ }^{22}$ It does not include the compensation of employees engaged in own-account capital formation. The central government wage bill also excludes the military.

${ }^{23}$ This value is in line with other studies, such as Baddock et al. (2015).

${ }^{24}$ Researchers have shown that error correction models have applications beyond estimating co-integrating relationships (De Boef and Keele 2008).

${ }^{25}$ See Chow and Kono (2017), Doyle (2015), Nooruddin and Simmons (2006), Nooruddin and Vreeland (2010), Remmer (2004), Rickard (2012), and Wellhausen (2015).

${ }^{26}$ When public sector conditions are included in the first year of a country's loan program, both L.Public Sector Condition and D.Public Sector Condition are coded as missing. This ensures the integrity of our empirical strategy. When a country's loan begins with a public sector condition, there is no appropriate comparison (i.e., no counterfactual).
} 
has a normal distribution. Differencing the series also helps to minimize the potential for a spurious correlation between two series exhibiting a time trend (De Boef and Keele 2008; Huber and Stephens 2001). $\mu_{\mathrm{i}}$ and $\lambda_{\mathrm{t}}$ capture country and year fixed effects, respectively.

In the error correction model, $\gamma$ and $\lambda$ are vectors of coefficients for the firstdifferences and lagged independent variables, respectively. Coefficients for the change variables $(\gamma)$ measure the short-term effects of a once-off change in a variable. The estimated coefficients for the level variables (i.e., lagged variables) $(\lambda)$ capture the effect of a once-off change in a variable dispersed across future time periods. The total effect of a once-off change can be found by dividing a variable's lagged coefficient by the coefficient on $\beta_{1}$.

While a fully specified ECM imposes fewer restrictive assumptions than other time-series models (De Boef and Keele 2008), the error correction model in combination with robust standard errors and year and countryfixed effects, as estimated here, produces very conservative results. ${ }^{27}$ While this estimation strategy carries some risk of discarding true hypotheses prematurely, it increases our confidence in the coefficients that do emerge as statistically significant.

Table 2 reports the results from the error correction model. Each column introduces a theoretically-relevant control variable. Our models are relatively parsimonious for both practical and theoretical reasons (Achen 2005). We have a relatively small sample size and introducing further control variables significantly reduces the number of observations. We are especially concerned about losing withincountry changes in loan conditions. We control for variables that may affect both public sector conditions and Compensation, including:

Democracy. A country's regime type may influence both the size of the public sector and the government's willingness to cut certain budget items (Nooruddin and Simmons 2006). We therefore control for regime type using the 21-point Polity scale. However, Democracy is not a robust predictor of Compensation in any of the estimated models.

Economic growth. A country with weak economic growth may have little choice but to accept the terms dictated by the IMF (Nooruddin and Vreeland 2010). At the same time, governments may cut the public sector wage bill of their own accord when facing negative economic growth. A spurious negative correlation could therefore emerge between public sector conditions and reductions in public sector spending. To avoid this possibility, we control for economic growth using the year-to-year percent change in GDP calculated using data from the World Bank's World Development Indicators. We find a positive coefficient between Growth and Compensation-suggesting that countries spend more on the public sector wage bill when the economy is growing faster.

GDP per capita. As countries become wealthier, governments may need to increase their supply of goods and services that would otherwise be undersupplied by the market. As a result, wealthier countries may have relatively larger public

\footnotetext{
${ }^{27}$ As a robustness test, we estimate the models with only country fixed effects. These results are reported in the Appendix.
} 
Table 2 Estimated effect of public sector loan conditions on the wage bill

(1)

$\mathrm{DV}=\Delta$. Compensation

L.Compensation

0.020

$(0.057)$

$-0.222$

$(0.155)$

$-0.577 * *$

$(0.227)$

L.Democracy

$\Delta$.Democracy

L.Growth

$\Delta$.Growth

L.GDP per capita

$\Delta$.GDP per capita

Constant

Observations

R-squared

Year fixed effects

Country fixed effects

Number of countries
(2)

(3)

(4)

0.053

(0.027)

$-0.066$

(0.095)

$-0.604 * * *$

-0.606 **

(0.214)

0.004

0.021

(0.217)

0.007

(0.032)

(0.039)

(0.031)

0.016

(0.021)

(0.032)

(0.022)

3.698**

$6.171^{* * * *}$

(1.569)

(1.835)

1.871

$3.851 * *$

(1.595)

(1.602)

$-0.041$

(0.049)

$-0.514 * * *$

(0.189)

$-0.448$

(0.613)

508

0.157

Yes

Yes

81

Error correction model with robust standard errors in parentheses and year and country fixed-effects; *** $p<0.01, * * p<0.05, * p<0.1$

sectors. Wealthier countries may also receive fewer IMF loan conditions, as suggested in some previous studies (Baumol 1993). To avoid a potentially spurious correlation, we control for GDP per capita. The coefficient on our key variable of interest-Public Sector Condition-does not change significantly after the addition of GDP per capita to the model.

Although these do not constitute the universe of all possible control variables, we believe they are the most theoretically relevant and the ones most likely to generate a spurious correlation between Public Sector Condition and Compensation. As a robustness check, we apply the method proposed by Altonji et al. (2005) and Chaudoin et al. (2016) to see how strong selection on unobservables would have to be in order to explain away our key result. We find that selection on unobservables would have to be two to three times as 
strong as selection on observables to account for the reported effects of public sector conditions.$^{28}$

\section{Results}

Public sector conditions are robustly correlated with short-term cuts to the wage bill, as reported in Table 2. The coefficients on $\Delta$.Public Sector Conditions report the estimated effects of adding a public sector condition to a country's loan program. In all models, the coefficients on $\Delta$.Public Sector Conditions are negatively signed and statistically significant, which indicate that the addition of a public sector condition to a country's loan program correlates with a short-term reduction in the wage bill. In the short-run at least, IMF conditions "work"; they engender spending cuts precisely where the Fund wants to see them - in this case, the public sector wage bill.

To investigate the durability of IMF-induced spending cuts, we calculate the long run multiplier (LRM) using the results from the error correction model. The long run multiplier (LRM) reports the total effect of public sector conditions on compensation: that is, the short-run effect plus any longer-run effects. These values are reported in Table 3. Using Bewley's (1979) method, we calculate the standard errors for the LRM.

The LRM and their associated standard errors show that public sector conditions are not significantly correlated with the wage bill in the long-run. ${ }^{29}$ None of the LRMs are statistically significant. ${ }^{30}$ Public sector conditions have no significant, lasting effect on the public sector wage bill. Although borrowers initially cut public sector spending in response to targeted IMF conditions, these cuts are not sustained over time.

This finding is consistent with the IMF's own assessment of public sector reform in borrowing countries. The Independent Evaluation Office (IEO) of the IMF concluded that reductions in public employment and public-sector wages induced by IMF programs are short-lived because they are easily reversed (Independent Evaluation Office $2003,10)$. The IEO reports that short-term declines in public sector wages are often followed by reversals because of "domestic pressures" (Independent Evaluation Office 2003). In Uganda, for example, the IMF identified public sector reform as a pressing issue, and in 1993, the IMF required the Ugandan government to eliminate 65,000 employees from the civil service as a condition of its loan. ${ }^{31}$ Although Uganda made good progress towards reaching this benchmark condition, it fell short by 25,000 employees. In 1994, the IMF ratcheted up the condition to a performance criterionthe most stringent form of conditionality - and increased the required cumulative reduction to 150,000 personnel. $^{32}$ Uganda met this condition, and the following year, the IMF dropped the public sector conditions from the country's loan program. ${ }^{33}$ Although the IMF asked for a freeze on net employment and continued vigilance on

\footnotetext{
28 These results are available from the authors upon request.

${ }^{29}$ For another example of statistically significant short-term effects that disappear over time see Chow and Kono (2017).

${ }^{30}$ Although the LRM are not statistically significant, they are all positive-suggesting that government spending on the wage bill may trend up over time after the initial cut.

${ }^{31}$ IMF document EBS/93/172

${ }^{32}$ IMF document EBS/94/157

33 IMF documents EBS/95/62 and EBS/95/173
} 
Table 3 Short and long run effects of the addition of a public sector loan condition

\begin{tabular}{lllll}
\hline & 1 & 2 & 3 & 4 \\
\hline Short Term Effect & $-0.577^{* *}$ & $-0.606^{* *}$ & $-0.637^{* * * *}$ & $-0.604^{* * * *}$ \\
& $(0.227)$ & $(0.252)$ & $(0.217)$ & $(0.214)$ \\
Long Run Effect & 12.51 & 11.91 & 1.53 & 1.16 \\
& $(46.56)$ & $(42.85)$ & $(3.08)$ & $(2.64)$ \\
\hline
\end{tabular}

Long run effects and the corresponding standard errors are calculated using Bewley's (1979) method to uncover the long run multipliers using the results from Table 2

wage increases, the Fund attached no binding conditions to these requests. Unconstrained by explicit public-sector conditions, the government, under intense domestic pressure, increased spending on the wage bill by $37 \%$ from 1995 to $1996 .{ }^{34}$ The government appeared unable (or unwilling) to maintain the IMF-mandated cuts in the face of strong political pressures at home. ${ }^{35}$ The Ugandan example illustrates that governments may reverse public sector reforms once targeted IMF loan conditions are removed from the country's loan. Although the IMF's own observations of backsliding are largely anecdotal, our results provide some of the first quantitative evidence of "backsliding."

\section{Substantive effects}

Despite the likelihood of backsliding, the short-run effects of public sector conditions are important. Even short-term cuts can reduce essential public services, such as health care and education, because the wage bill is a key input in the provision of health and education (Forni and Novta 2014). Public sector employment cuts in Estonia, for example, were blamed for lengthier medical waiting lists (International Labour Office 2012). Similarly, in Ireland, temporary cuts to public sector employment made in response to the country's 2010 loan program, reduced access to health services (Burke 2009). In sum, short-term cuts to the wage bill can have important consequences.

In Bolivia, for example, spending on the wage bill fell sharply after the addition of a public sector condition to the country's loan program. The Bolivian government borrowed from the IMF continuously from 1986 to 2006. In 1996, a public sector condition was added to its loan program and spending on public sector employees subsequently fell by $3.2 \%$ year-on-year. The public sector condition remained in place until 1999. After it was removed from Bolivia's loan program, spending on the wage bill increased by $0.43 \%$ the following year. By 2002 , the wage bill had risen to nearly the same level as its pre-1996 value, again illustrating backsliding by governments in response to domestic politics once IMF conditions expire.

\footnotetext{
${ }^{34}$ IMF document EBS/96/61 and EBS 96/170

${ }^{35}$ Backsliding occurs in other politically sensitive policy areas, such as trade (Wei and Zhang 2010, 80; Bown and Tovar 2011).
} 


\section{Conclusion and implications}

Nearly 70 years after the first IMF loan, the effects of IMF lending remain contested. In this paper, we offer a straightforward explanation for the ongoing disagreement over the effects of IMF loans. We argue that because loan conditions vary between IMF programs, IMF loans do not have a single, invariant effect on all borrowers. Differences in the conditions attached to IMF loans have consequences for the effects of IMF lending. To accurately assess the effects of IMF lending, scholars must disaggregate loan conditions and link specific conditions to specific outcomes, as we do in this study.

We show that IMF loan conditions matter. IMF loan programs affect policy outcomes through conditionality. We demonstrate this with respect to the public sector. The addition of at least one public sector condition to a country's loan program is robustly correlated with a reduction in the public sector wage bill. This finding contributes novel evidence to the ongoing debate over which mechanisms link IMF programs to policy change (Dreher 2009). Our contribution is to provide a convincing test of whether conditionality is one of the mechanisms through which IMF lending has its effects. If governments choose to ignore their loan conditions, we would find no significant difference in the wage bill between countries with and without public sector conditions. Such a null result would cast doubt on the plausibility of conditionality as a key mechanism. However, we find that governments facing public sector loan conditions make deeper cuts to the wage bill than governments under IMF programs without public sector conditions, which suggests that conditions matter.

While targeted conditions have a significant reductive effect on the wage bill in the short run, these effects are not sustained over time. We speculate that backsliding due to domestic pressures explains why public sector conditions have no robust, long-term effect on the wage bill. Since cuts to the public sector fall on politically powerful groups, borrowers will only cut the public sector when they have to - that is, when they receive targeted loan conditions (rather than generic loan conditions). Once the knife of conditionality is no longer at a government's throat, governments will increase public sector spending to appease powerful domestic constituents. Such politically-motivated backsliding may explain why IMF conditions fail to engender long-term public sector reform.

Our findings suggest that previous studies may have underestimated countries' compliance with IMF conditions. Some studies report that IMF loans have no meaningful effect on government policy because of non-compliance with loan conditions (e.g., Wei and Zhang 2010; Bown and Tovar 2011). And conventional wisdom holds that governments rarely implement IMF-mandated public sector reforms. Yet we find evidence that -at least in the short-term-governments with explicit public sector conditions in their IMF programs cut spending on the wage bill. ${ }^{36}$ We believe that linking specific conditions to specific outcomes is an innovation that accounts for our novel finding. Since most IMF loans do not mandate cuts to the public sector, failure to find a robust correlation between all IMF programs and public sector reforms cannot be interpreted as "non-compliance" or ineffectiveness. Instead, the appropriate sub-sample

\footnotetext{
${ }^{36}$ Nooruddin and Simmons (2006) suggest that borrowing countries will cut social spending to protect the public sector wage bill. But as we have shown, borrowing countries that receive targeted public sector conditions have less flexibility to choose where to make budget cuts.
} 
of IMF programs to examine are those with explicit public sector conditions. By disaggregating loans and differentiating those that contain targeted conditions from those that do not, we come to different conclusions than other authors. This leads us to believe that by ignoring the variation in IMF loan conditions, previous studies may underestimate compliance and possibly misdiagnose the effects of IMF lending.

Disaggregating loans conditions may help to resolve further puzzles about IMF lending, such as the varied political responses to IMF programs. Dreher and Gassebner (2012), for example, find no consistently robust effect of IMF loans on government crises. ${ }^{37}$ One reason for the varied political responses to IMF programs may be differences in loan conditions, which engender different types of reforms with varied distributional consequences. An improved understanding of the political and economic consequences of international sovereign lending may come from a disaggregated approach to conditionality, as adopted in our study.

The evidence we find of backsliding calls into question arguments about "political cover." If governments use the IMF as political cover to implement desired reforms, it is unlikely that they would reverse these reforms once the condition expires. We speculate that political cover may not be the predominant negotiating posture of many governments, particularly with respect to labor and public sector employment issues. ${ }^{38}$ Further research is needed to clarify the precise conditions under which the political cover argument is most appropriate.

Our results have thought-provoking policy implications. Over the past decades, the IMF aimed to provide governments with greater "ownership" of their loan programs. To this end, the IMF often stipulated only general fiscal targets and let governments decide for themselves where in the budget to make the necessary cuts. As we demonstrate, politically difficult spending cuts are unlikely to happen when governments have ownership over their loan programs. Reforms in contentious areas, such as the public sector, will only occur when explicitly required by the IMF. Paradoxically, then, the IMF's efforts to give governments greater autonomy in deciding where to make budget cuts may delay the implementation of economic reforms. Governments with ownership over their programs will cut spending where it is least politically painful rather than where it is most needed.

This study has implications beyond IMF programs. Public sector conditions in IMF programs provide an example of reforms introduced through external interventions via other multilateral and regional institutions (e.g., the World Bank, the European Central Bank, etc.) and bilateral financial assistance programs. The lessons reported in the current study are, in principle, applicable to conditionality in a variety of international assistance packages. In this broader context, our results suggest that international lenders can use loan conditions to engender cuts to specific budget items but once this leverage is gone, the reforms tend not to stick.

\footnotetext{
${ }^{37}$ In contrast, however, Smith and Vreeland (2006) find evidence that IMF loans affect leaders' survival in office.

${ }^{38}$ See also Nelson (2014) for further suggestive evidence on this point.
} 
Open Access This article is distributed under the terms of the Creative Commons Attribution 4.0 International License (http://creativecommons.org/licenses/by/4.0/), which permits unrestricted use, distribution, and reproduction in any medium, provided you give appropriate credit to the original author(s) and the source, provide a link to the Creative Commons license, and indicate if changes were made.

\section{References}

Achen, C. H. (2005). Let's put garbage-can regressions and garbage-can Probits where they belong. Conflict Management and Peace Science, 22(4), 327-339.

Aidi, H. D. (2009). Redeploying the state: Corporatism, neoliberalism, and coalition politics. New York: Palgrave Macmillan.

Altonji, J. G., Elder, T. E., \& Taber, C. R. (2005). Selection on observed and unobserved variables: Assessing the effectiveness of Catholic schools. Journal of Political Economy, 113(1), 151-184.

Baddock, E., Lang, P., \& Srivastava, V. (2015). Size of the public sector: Government wage bill and employment. Washington, DC: The World Bank.

Bas, M. A., \& Stone, R. W. (2014). Adverse selection and growth under IMF programs. The Review of International Organizations, 9(1), 1-28. https://doi.org/10.1007/s11558-013-9173-1.

Baumol, W. J. (1993). Health care, education and the cost disease: A looming crisis for public choice. Public Choice, 77, 17-28.

Bewley, R. A. (1979). The direct estimation of the equilibrium response in a linear model. Economic Letters, 3(4), 357-361.

Bienen, H. S., \& Gersovitz, M. (1985). Stabilization, conditionality, and political stability. International Organization, 39, 729-754.

Biersteker, T. J. (1990). Reducing the role of the state in the economy: A conceptual exploration of IMF and World Bank prescriptions. International Studies Quarterly, 34, 477-492.

Bird, G. (1996). Borrowing from the IMF: The policy implications of recent empirical research. World Development, 24, 1753-1760.

Bird, G., \& Willett, T. (2004). IMF conditionality, implementation and the new political economy of ownership. Comparative Economic Studies, 46, 423-450.

Blaydes, L. (2011). Elections and distributive politics in Mubarak's Egypt. New York: Cambridge University Press.

Bown, C. P., \& Tovar, P. (2011). Trade liberalization, antidumping, and safeguards: Evidence from India's tariff reform. Journal of Development Economics, 96(1), 115-125.

Bulír, A., \& Moon, S. (2004). Is fiscal adjustment more durable when the IMF is involved? Comparative Economic Studies, 46(3), 373-399. https://doi.org/10.1057/palgrave.ces.8100051.

Bulír, A., \& Moon, S. (2006). Long-term fiscal developments and IMF conditionality: Is there a link? In In IMF-Supported Programs: Recent Staff Research, edited by Ashoka Mody and Alessandro Rebucci. Washington, DC: International Monetary Fund.

Burke, S. (2009). Boom to bust: Its impact on Irish health policy and health services. Irish Journal of Public Policy, 2(1).

Calvo, E., \& Murillo, M. V. (2004). "Who delivers? partisan clients in the argentine electoral market." American Journal of Political Science 48(4):742-57.

Caraway, T. L., Rickard, S. J., \& Anner, M. S. (2012). International negotiations and domestic politics: The case of IMF labor market conditionality. International Organization, 66, 27-61.

Chandra, K. (2004). Why ethnic parties succeed: patronage and ethnic headcounts in India. New York: Cambridge University Press.

Chandra, K. (2007). Why ethnic parties succeed: Patronage and ethnic head counts in India. New York: Cambridge University Press.

Chapman, T., Fang, S., Li, X., \& Stone, R. W. (2015). Mixed signals: IMF lending and capital markets. British Journal of Political Science, 47(2), 329-349.

Chaudoin, S., Hays, J., \& Hicks, R. (2016). Do we really know the WTO cures cancer? British Journal of Political Science, 1-26. https://doi.org/10.1017/S000712341600034X.

Chow, Wilfred, and Daniel Y. Kono. (2017). Entry, Credibility, and Trade Policy: Why Some Autocrats Like International Trade. International Studies Quarterly, 61(4), 892-906.

Clements, B., Gupta, S., Karpowicz, I., \& Tareq, S. (2010). Evaluating government employment and compensation. In IMF technical notes and manuals. Washington, DC: International Monetary Fund. 
Clements, B., Gupta, S., \& Nozaki, M. (2013). What happens to social spending in IMF-supported Programmes? Applied Economics, 45(28), 4022-4033.

Copelovitch, M. S. (2010). The International Monetary Fund in the global economy: Banks, bonds, and bailouts. New York: Cambridge University Press.

Das, S. K. (1998). Civil Service Reform and Structural Adjustment. Delhi: Oxford University Press.

De Boef, S., \& Keele, L. (2008). Taking time seriously. American Journal of Political Science, 52(1), 184 200.

Doyle, D. (2015). Remittance and social spending. American Political Science Review, 109(4), 785-802.

Dreher, A. (2003). The influence of elections on IMF Programme interruptions. Journal of Development Studies, 36(6), 101-120.

Dreher, A. (2006). IMF and economic growth: The effects of programs, loans, and compliance with conditionality. World Development, 34(5), 769-788.

Dreher, A. (2009). IMF conditionality: Theory and evidence. Public Choice, 141(1-2), 233-267. https://doi. org/10.1007/s11127-009-9486-Z.

Dreher, A., \& Gassebner, M. (2012). Do IMF and World Bank programs induce government crises? An empirical analysis. International Organization, 66, 329-358.

Dreher, A., \& Jensen, N. M. (2007). Independent actor or agent? An empirical analysis of the impact of U.S. interests on International Monetary Fund conditions. Journal of Law and Economics, 50, 105-124.

Dreher, A., Sturm, J.-E., \& Vreeland, J. R. (2015). Politics and IMF conditionality. Journal of Conflict Resolution, 59(1), 120-148.

Easterly, W. (2001). The elusive quest for growth: Economists' adventures and misadventures in the tropics. Cambridge, Mass: The MIT Press.

Forni, L., \& Novta, N. (2014). Public employment and compensation reform during times of fiscal consolidation. In IMF working paper WP/14/192. Washington, DC: International Monetary Fund.

Gandhi, J. (2010). Political institutions under dictatorship. New York: Cambridge University Press.

Garrett, G., \& Lange, P. (1991). Political responses to interdependence: What's 'left' for the left? International Organization, 45(4), 539-564.

Garuda, G. (2000). The distributional effects of IMF programs: A cross-country analysis. World Development, 28(6), 1031-1051. https://doi.org/10.1016/S0305-750X(00)00002-4.

Gelb, A., Knight, J. B., \& Sabot, R. H. (1991). Public sector employment, rent seeking and economic growth. The Economic Journal, 101, 1186-1199.

Goldsmith, A. A. (1999). Africa's overgrown state reconsidered: Bureaucracy and economic growth. World Politics, 51, 520-546.

Gould, E. (2003). Money talks: Supplementary financiers and International Monetary Fund conditionality. International Organization, 57, 551-586.

Gould, E. (2006). Money talks: The International Monetary Fund, conditionality, and supplementary financiers. Palo Alto: Stanford University Press.

Greene, K. F. (2007). Why dominant parties lose: Mexico's democratization in comparative perspective. New York: Cambridge University Press.

Hajro, Z., \& Joyce, J. P. (2009). A true test: Do IMF programs hurt the poor? Applied Economics, 41(3), 295306. https://doi.org/10.1080/00036840601007229.

Heckman, J. J. (1979). Sample selection bias as a specification error. Econometrica, 47(1), 53-161.

Huber, E., \& Stephens, J. D. (2001). Development and crisis of the welfare state: Parties and politics in global markets. Chicago: University of Chicago Press.

Independent Evaluation Office. (2003). Fiscal adjustment in IMF-supported programs. Washington, DC: International Monetary Fund.

International Labour Office. (2012). Public sector adjustment in Europe. Brussels: ILO.

International Monetary Fund. (2001). Government finance statistics manual. Washington, DC: IMF.

International Monetary Fund. (2014). Government finance statistics manual. Washington, DC: IMF.

Ivanova, Anna, Wolfgang Mayer, Alex Mourmouras, and George Anayiotos. 2003. "What determines the implementation of IMF-supported programs?" International Monetary Fund Working Paper, no. WP/03/ 8.

Joyce, J. P. (2004). Adoption, implementation and impact of IMF Programmes: A review of the issues and evidence. Comparative Economic Studies, 46(3), 451-467. https://doi.org/10.1057/palgrave.ces.8100052.

Keefer, P. (2007). "Clientelism, credibility, and the policy choices of young democracies." American Journal of Political Science 51(4):804-21.

Kentikelenis, A. E., Stubbs, T. H., \& King, L. P. (2015). Structural adjustment and public spending on health: Evidence from IMF programs in low-income countries. Social Science \& Medicine, 126, 169-176. 
Kentikelenis, A. E., Stubbs T. H, \& King L. P. (2016). "IMF conditionality and development policy space, 1985-2014." Review of International Political Economy 23 (4):543-82. https://doi.org/10.1080 /09692290.2016.1174953.

Khabele, M. (1990). Structural adjustment and the employment challenge in Lesotho. Institute of Southern African Studies: National University of Lesotho.

Lee, C. K., \& Strang, D. (2006). The international diffusion of public-sector downsizing: Network emulation and theory-driven learning. International Organization, 60, 883-910.

Lindauer, D. L. (1994). Government Pay and Employment Policies and Economic Performance. In D. L. Lindauer \& B. Nunberg (Eds.), Rehabilitating Government: Pay and Employment Reform in Africa. Washington, DC: World Bank.

Lust-Okar, E. (2006). Elections under authoritarianism: Lessons from Jordan. Democratization, 13, 456-471.

Mahdavi, S. (2004). Shifts in the composition of government spending in response to external debt burden." World Development 32:1139-57.

Magaloni, B. (2008). Voting for autocracy: Hegemonic party survival and its demise in Mexico. New York: Cambridge University Press.

Mercer-Blackman, V., \& Unigovskaya, A. (2004). Compliance with IMF program indicators and growth in transition economies. Emerging Markets Finance and Trade, 40(3), 55-83.

de Mesquita, B., Bruce, A. S., Siverson, R., \& Morrow, J. (2003). The logic of political survival. Cambridge, MA: MIT Press.

Nelson, S. C. (2014). Playing favorites: How shared beliefs shape the IMF's lending decisions. International Organization, 68(2), 297-328.

Nooruddin, Irfan, and Nita Rudra. 2009. "Are developing countries really defying the embedded liberalism compact?"

Nooruddin, Irfan, and Nita Rudra. 2014. "Are developing countries really defying the embedded liberalism compact?" World Politics, 66 (4):603-40.

Nooruddin, I., \& Simmons, J. W. (2006). The politics of hard choices: IMF programs and government spending. International Organization, 60, 1001-1033.

Nooruddin, I., \& Vreeland, J. R. (2010). The effects of IMF programs on public wages and salaries. In J. Clapp \& R. Wilkinson (Eds.), Global Governance, Poverty and Inequality (pp. 90-111). London: Routledge.

Nsouli, Saleh M., Rouben Atoian, and Alex Mourmouras. 2004. "Institutions, program implementation, and macroeconomic performance." IMF Working Paper. IMF Institute and Middle East and Central Asia Department.

Nunberg, B., \& Nellis, J. (1992). Civil service reform and the World Bank. Washington, DC: World Bank.

Oberdabernig, D. A. (2013). Revisiting the effects of IMF programs on poverty and inequality. World Development, 46, 113-142.

Petersson, L. (1993). Structural adjustment and economic Management in a Dependent Economy: The case of Lesotho. In M. Blomstrom \& M. Lundahl (Eds.), Economic crisis in Africa: Perspectives on policy responses (pp. 118-142). New York: Routledge.

Pop-Eleches, G. (2009). From economic crisis to reform: IMF programs in Latin America and Eastern Europe. Princeton: Princeton University Press.

Rama, M. (1999). Public sector downsizing: An introduction. The World Bank Economic Review, 13, 1-22.

Rapley, J. (2002). Understanding development: Theory and practice in the third worlds. Boulder: Lynne Rienner Publishers.

Remmer, K. L. (2004). Does foreign aid promote the expansion of government? American Journal of Political Science, 48(1), 77-92. https://doi.org/10.1111/j.0092-5853.2004.00057.x.

Remmer, K. L. (2007). "The political economy of patronage: expenditure patterns in the argentine provinces, 1983-2003." Journal of Politics 69(2):363-77.

Rickard, S. J. (2012). Welfare versus subsidies: Governmental spending decisions in an era of globalization. The Journal of Politics, 74(4), 1171-1183.

Rickard, S. J., \& Caraway, T. L. (2014). International negotiations in the shadow of elections. International Organization, 68(3), 701-720.

Robinson, J. A., \& Verdier, T. (2013). The political economy of clientelism. The Scandinavian Journal of Economics 115(2):260-91.

Rodrik, D. (2000). What drives public employment in developing countries? Review of Development Economics, 4, 229-243.

Schiavo-Campo, S., de Tommaso, G., \& Mukherjee, A. (1997). An international statistical survey of government employment and wages. Washington, DC: World Bank.

Shepherd, Geoffrey. 2003. "Civil service reform in developing countries: Why is it going badly?" in . 
Smith, A., \& Vreeland, J. R. (2006). The Survival of Political Leaders and IMF Programs. In G. Ranis, J. R. Vreeland, \& S. Kosack (Eds.), Globalization and the Nation State: The Impact of the IMF and the World Bank. New York: Routledge.

Steinwand, M. C., \& Stone, R. W. (2008). The International Monetary Fund: A review of the recent evidence. The Review of International Organizations, 3, 123-149.

Stevenson, G. (1992). How public sector pay and employment affect labor markets. Washington, DC: World Bank.

Stone, R. W. (2008). The scope of IMF conditionality. International Organization, 62(4), 589-620.

Vreeland, J. R. (2002). The effect of IMF programs on labor. World Development, 30, 121-139.

Vreeland, J. R. (2003). The IMF and economic development. New York: Cambridge University Press.

Vreeland, J. R. (2006). IMF program compliance: Aggregate index vs. policy specific research strategies. The Review of International Organizations, 1, 359-378.

van de Walle, N. (2001). African economies and the politics of permanent crisis, 1979-1999. New York: Cambridge University Press.

Wei, S.-J., \& Zhang, Z. (2010). Do external interventions work? The case of trade reform conditions in IMF supported programs. Journal of Development, 92(1), 71-81.

Wellhausen, R. L. (2015). Bondholders vs. Direct Investors? Competing Responses to Expropriation. Bondholders vs. Direct Investors? Competing Responses to Expropriation, 59(4), 750-764. 